\title{
Dose- and type-dependent effects of long-chain fatty acids on adipogenesis and lipogenesis of bovine adipocytes
}

\author{
Chen Yanting, ${ }^{*}$ Q. Y. Yang, ${ }^{*}$ G. L. Ma, ${ }^{*} M$. Du, ${ }^{*}$ J. H. Harrison,$\dagger^{1}$ and E. Block \\ *Department of Animal Science, Washington State University, Pullman 99164 \\ †Department of Animal Science, Washington State University, Puyallup 98731 \\ $\ddagger$ Church and Dwight Animal Nutrition, Princeton, NJ 08543
}

\section{ABSTRACT}

Differentiation and lipid metabolism of adipocytes have a great influence on milk performance, health, and feed efficiency of dairy cows. The effects of dietary long-chain fatty acids (FA) on adipogenesis and lipogenesis of dairy cows are often confounded by other nutritional and physiological factors in vivo. Therefore, this study used an in vitro approach to study the effect of dose and type of long-chain FA on adipogenesis and lipogenesis of bovine adipocytes. Stromal vascular cells were isolated from adipose tissue of dairy cows and induced into mature adipocytes in the presence of various long-chain FA including myristic, palmitic, stearic, oleic, or linoleic acid. When concentrations of myristic, palmitic, and oleic acids in adipogenic mediums were 150 and $200 \mu M$, the induced mature adipocytes had greater lipid content compared with other concentrations of FA. In addition, mature adipocytes induced at $100 \mu M$ stearic acid and $300 \mu M$ linoleic acid had the greatest content of lipid than at other concentrations. High concentrations of saturated FA were more toxic for cells than the same concentration of unsaturated FA during the induction. When commitment stage was solely treated with FA, the number of differentiated mature adipocytes was greater for oleic and linoleic acids than other FA. When the maturation stage was treated with FA, the number of mature adipocytes was not affected, but the lipid content in adipocytes was affected and ranked oleic $>$ linoleic $>$ myristic $>$ stearic $>$ palmitic. In summary, this study showed that adipogenesis and lipogenesis of bovine adipocytes were differentially affected by long-chain FA, with unsaturated FA more effective than saturated FA.

Key words: fatty acid, adipogenesis, lipogenesis, stromal vascular cell, dairy cow

Received June 9, 2017.

Accepted October 5, 2017.

${ }^{1}$ Corresponding author: jhharrison@wsu.edu

\section{INTRODUCTION}

Adipose tissue is a heterogeneous cellular depot that stores and releases fatty acids (FA) to maintain energy homeostasis of animals. The compartment is composed of adipocytes and stromal vascular cells (SVC). The SVC include endothelial cells, immune and nerve cells, mesenchymal stem cells (MSC), and preadipocytes (Ouchi et al., 2011). Mesenchymal stem cells are multipotent stem cells and able to differentiate into adipocytes, myocytes, osteoblasts, and chondrocytes depending on niche cues (Gesta et al., 2007). The function of MSC and preadipocytes is to renew and replace senesced mature adipocytes in adipose tissue.

Adipogenesis from MSC to mature adipocytes is practically categorized into 2 phases (Lowe et al., 2011). The first phase, known as the commitment stage, is the determining point when the adipogenic lineage of MSC become preadipocytes. Morphologically, the preadipocyte is difficult to distinguish from the MSC, but has lost the capacity to differentiate into other cell types (Du et al., 2015). The number of adipocytes can be affected by factors that are able to influence the adipogenic lineage in this stage (Jo et al., 2009). In the second phase, known as the maturation stage, committed preadipocytes obtain the characteristics of mature adipocytes, such as the formation of lipid droplets, insulin sensitivity, and adipokine secretions. The adipocyte size is determined in this stage (Jo et al., 2009). Each stage is controlled by well-organized, relatively independent, and complicated signal cascades (Rosen and MacDougald, 2006).

Adipogenesis presents in all life stages of mammals, but the ability to form new adipocytes declines as the animal ages (Tang et al., 2008; Du et al., 2013, 2015). In dairy cows, physiological changes in adipose tissue are dramatic during the lactation period (McNamara and Baldwin, 2000). In the first $60 \mathrm{~d}$ after calving, approximately $11 \mathrm{~kg}$ of triglycerides is mobilized from adipose tissue, and around $35 \mathrm{~kg}$ of triglycerides is re-deposited in the following $60 \mathrm{~d}$ (McNamara and 
Baldwin, 2000). Besides the mass change, the adipocyte number is also shifted during the lactation period (Smith and McNamara, 1990). Because adipose tissue is critical for energy balance, feed efficiency, health, and milk performance of dairy cows, it is essential to understand the environmental factors affecting adipogenesis and lipogenesis of bovine adipocytes (McNamara and Baldwin, 2000; McNamara et al., 2016).

Long-chain FA are building blocks for lipid droplets in adipocytes and can be actively involved in the regulation of adipogenesis and lipogenesis. For example, the peroxisome proliferator activated receptor gamma $(\boldsymbol{P P A R G})$ is a well-known master regulator of adipogenesis and lipogenesis in adipocytes, and can control the expression of other adipogenic genes (Tontonoz et al., 1994b). Smith et al. (2009) observed the metabolic health of transition cows was greatly improved through attenuation of body fat mobilization when cows were infused intrajugularly with thiazolidinediones, an agonist of PPARG. Fatty acids are natural ligands that activate the expression of PPARG (Rosen et al., 2000), and different FA have been observed to possess various potencies in activation of PPARG in bovine mammary gland epithelial cells and kidney cells (Kadegowda et al., 2009a; Thering et al., 2009a). However, effects of FA on adipogenesis and lipogenesis in bovine adipocytes are not well defined.

In dairy cows, myristic, palmitic, stearic, oleic, and linoleic acids are the most abundant FA in the digestive tract and blood; also, each FA can differentially affect the metabolism of body tissues and organs (Boerman et al., 2015). Rumen fermentation can be negatively affected by biohydrogenation of oleic and linoleic acids, and the intermediate products of biohydrogenation, such as C18:1 trans-10 and C18:2 trans-10,cis-12, are also identified as strong precursors that inhibit milk fat synthesis (Chilliard et al., 2007). The mammary gland prefers palmitic acid for milk fat synthesis, whereas adipose tissue prefers stearic acid for lipogenesis (Loften et al., 2014; Rico et al., 2014). Obviously, each FA not only serves as an energy source, but also has some special functions in regulating physiological metabolism. Improving our understanding of the roles of these FA on adipogenesis and lipid accumulation in the adipocyte could be beneficial for fully understanding lactation and health of dairy cows as regulated by FA.

The objective of this study was to understand the roles of major long-chain FA in adipogenesis and lipogenesis of bovine adipocytes and help to develop nutritional strategies to optimize adipocyte development and lipid metabolism of dairy cows. Our hypothesis was that long-chain FA would have different effects on adipogenesis and lipogenesis of bovine stromal vascular cells isolated from dairy cows dependent on the dose and specific FA. In the first study, the dose-dependent effects of FA on adipogenesis were investigated. In the second study, selected concentrations of each FA were used to study their effects on adipogenic differentiation and maturation, respectively.

\section{MATERIALS AND METHODS}

All experimental procedures involving animals were conducted with the guidelines of the Washington State University Animal Care and Use Committee.

\section{Isolation of SVC and Adipogenic Induction}

Five Holstein dairy cows (BW, $691 \pm 18.8 \mathrm{~kg}$; DIM, $61 \pm 5.9$; milk yield, $54.2 \pm 3.36 \mathrm{~kg} / \mathrm{d}$ ) were used as adipose tissue donors. Adipose tissue was taken from alternate sides of the tail head as described by Smith and McNamara (1989). After the biopsy, fresh tissue was kept on ice and immediately transported to the laboratory for processing. Tissue was washed with PBS and minced into small pieces, and then digested in a medium containing 0.75 unit $/ \mathrm{mL}$ of collagenase D (no. 11088874103, Roche, Pleasanton, CA) and 1.0 unit/mL of Dispase type II (no. 4942078001, Roche) for $30 \mathrm{~min}$ in an Eppendorf $\mathrm{AG}$ shaking incubator (New Brunswick, Germany) at $90 \mathrm{rpm}$ at $37^{\circ} \mathrm{C}$. The lysate was filtered with $100-\mu \mathrm{m}$ nylon mesh (Thermo Fisher Scientific, Asheville, NC) and centrifuged at $500 \times g$ for $5 \mathrm{~min}$ at $4^{\circ} \mathrm{C}$. The precipitated pellet was resuspended and seeded in Dulbecco's modified Eagle medium/F-12 (DMEM/F-12, no. 12500-096, Thermo Fisher, Waltham, MA) with $10 \%$ fetal bovine serum (FBS; no. SH30401, HyClone, South Logan, UT) and $1 \%$ antibiotics (no. 15070063, Thermo Fisher). The cell culture was maintained in a $37^{\circ} \mathrm{C}$ and $5 \% \mathrm{CO}_{2}$ incubator (Eppendorf AG). Culture medium was renewed every $48 \mathrm{~h}$.

The SVC reached about 80 to $90 \%$ confluence after 5 to $7 \mathrm{~d}$ of culture, subculture ( $<2$ passages) was used to obtain sufficient SVC for studies. The SVC were washed with PBS buffer and digested in trypsin-EDTA solution (no. SLBN6048V, Sigma) in an incubator for $\sim 10 \mathrm{~min}$ until cells were detached from the inside surface of the plates. When cells were detached, fresh DMEM/F-12 containing FBS and antibiotics was added to the medium to cease the activity of trypsin. Collected cells from 5 donor animals were mixed and used for experiments. Cell treatments were initiated after SVC reached $100 \%$ confluence.

Adipogenic induction was initiated using a standard adipogenic cocktail (Yang et al., 2013). The first $4 \mathrm{~d}$ was considered as the commitment stage when cellular morphology was spindle-like and lipid droplets were not 
seen under the microscope (Gupta et al., 2012; Yang et al., 2013). The basal culture medium was DMEM/F-12 containing FBS and antibiotics supplemented with 0.5 $\mathrm{m} M$ isobutyl-methylxanthine (no. 15879, Sigma), $1 \mu M$ dexamethasone (no. D4902, Sigma), and $5 \mu \mathrm{g} / \mathrm{mL}$ of insulin (no. I1507, Sigma). The last $4 \mathrm{~d}$ was considered as the maturation stage when lipid droplets appeared in cytosol and cellular morphology became oval (Gupta et al., 2012; Yang et al., 2013). The basal culture medium was DMEM/F-12 containing serum and antibiotics supplemented with $5 \mu \mathrm{g} / \mathrm{mL}$ of insulin.

Long-chain FA used in the experiment included myristic acid (C14:0, M3128, Sigma), palmitic acid (C16:0, P0500, Sigma), stearic acid (C18:0, S4751, Sigma), oleic acid (cis-9, C18:1, O1008, Sigma), and linoleic acid (C18:2 cis-9,cis-12, L1376, Sigma). Because SFA were difficult to dissolve in water, all FA were saponified with equimolar of $\mathrm{NaOH}$ at $65^{\circ} \mathrm{C}$. After saponification, the soap was prepared with $30 \mathrm{~m} M$ stock solution by adding $100 \%$ ethanol and stored at $-20^{\circ} \mathrm{C}$ until use (Kadegowda et al., 2009b).

\section{Dose-Dependent Effects of FA on Adipogenesis}

In the dose-dependent study, myristic, palmitic, oleic, and linoleic acids were individually supplemented in basal culture mediums at 0 (control), 150, 250, or $300 \mu M$. Culture medium was refreshed every $48 \mathrm{~h}$. For stearic acid, concentrations above $150 \mu M$ stearic acid were toxic to SVC, and thus, the doses were adjusted to $0,50,100$, and $150 \mu M$. On $8 \mathrm{~d}$, cells were collected for mRNA extraction and oil red $\mathrm{O}$ staining. Each treatment had 3 replicates.

\section{Commitment Stage Treated by FA}

Appropriate concentrations of each FA for adipogenesis observed in the dose-dependent study was used in following studies. The SVC were treated by $250 \mu M$ myristic, palmitic, oleic, and linoleic acids and 100 $\mu M$ stearic acid only in the commitment stage. Culture medium was refreshed every $48 \mathrm{~h}$. On d 4 and 8 of adipogenic differentiation, cells were collected for mRNA extraction. On d 8, cells were also stained by 4',6-diamidino-2-phenylindole (no. 422801, BioLegend, San Diego, CA) for cell number counting using ImageJ (National Institutes of Health, https://imagej.nih.gov/ $\mathrm{ij} /$ ), and oil red $\mathrm{O}$ staining for lipid quantification (Yang et al., 2013). Each treatment had 4 replicates.

\section{Maturation Stage Treated by FA}

The SVC were treated with $250 \mu M$ myristic, palmitic, oleic, and linoleic acids and $100 \mu M$ stearic acid only during the differentiation stage. On d 8, cells were collected for mRNA extraction. Different replicates were also stained by 4',6-diamidino-2-phenylindole and oil red O staining. Each treatment had 4 replicates.

\section{mRNA Expression}

Total RNA was isolated by a Trizol reagent (no. 15596018, Thermo Fisher) followed by purification using Qiagen RNA columns (no. 433155595, Qiagen, Valencia, CA). Concentration and purity of isolated mRNA were quantified and assessed by NanoDrop 2000. The integrity of mRNA was verified by $1.5 \%$ of agarose gel electrophoresis. For each sample, $500 \mathrm{ng}$ of isolated mRNA was reversed to cDNA by reverse PCR using iScript cDNA Synthesis Kit (no. 170-8891, BioRad, Hercules, CA).

Abundance of mRNA expression was quantified with quantitative real-time PCR (qPCR, Bio-Rad IQ5). Briefly, $10-\mu \mathrm{L}$ reaction system was used, including $5 \mu \mathrm{L}$ of $2 \times$ Qfast Green Mastermix (no. NJ1601, EarthOx Life Sciences, Millbrae, CA), 2.5- $\mu$ L (12.5 ng) cDNA, a $0.4-\mu \mathrm{L}$ mixture $(10 \mu M)$ of forward and reverse primers, and $2.1 \mu \mathrm{L}$ of double-distilled $\mathrm{H}_{2} \mathrm{O}$. Reactions were as follows: 1 cycle for $10 \mathrm{~min}$ at $95^{\circ} \mathrm{C}$ (initial denaturation); 40 cycles at $95^{\circ} \mathrm{C}$ for $15 \mathrm{~s}$ (denaturation) and at $60^{\circ} \mathrm{C}$ for $1 \mathrm{~min}$ (annealing and reading of fluorescence).

Primers were designed to span exon-exon boundaries to avoid the amplification of genomic DNA and were verified in National Center of Biotechnology Information (NCBI) genomic database for avoiding nonspecific amplification. The expected size of cDNA was also compared with size of qPCR products with use of $2 \%$ agarose gel. The unique peak of the melting curve in the $\mathrm{qPCR}$ reaction was also used to verify a single amplification product.

The sequences and amplification sizes of the primers are shown in Supplemental Table S1 (https://doi.org/ 10.3168/jds.2017-13312). Eukaryotic translation initiation factor 3 subunit K (EIF3K), ubiquitously expressed prefoldin like chaperone $(U X T)$, and topoisomerase II $\beta$ (TOP2B) were used as internal controls for normalizing mRNA expression of target genes (Bonnet et al., 2013). In the dose-dependent study, mRNA expressions of PPARG, FA binding protein 4 (FABP 4), acetyl CoA carboxylase $1(A C C 1)$, and fatty acid synthases $(F A S N)$ were analyzed. When SVC were treated by FA either in the commitment stage or maturation stage, mRNA expressions of CCAAT/enhanced binding protein delta $(C E B P D)$, forkhead box protein A2 (FOXA2), Kruppel like factor 5 (KLF5), platelet derived growth factor receptor alpha (PDGFA), and zinc figure protein 423 (ZFP423) were analyzed on d 4; the mRNA expressions of PPARG, CCAAT/enhanced binding protein alpha 
( $C E B P A)$, sterol regulator element binding protein 1 (SREBP1C), ACC1, FASN, hormonal sensitive lipase $(H S L)$, adipose triacylglycerol lipase $(A T G L)$, glucose transport 4 (GLUT4), FABP 4, and leptin were analyzed on $\mathrm{d} 8$. The relative mRNA expression was quantified using the method of $2^{-\Delta \Delta C T}$, where $\Delta \mathrm{C}_{\mathrm{T}}=\mathrm{C}_{\mathrm{T}}$ of target gene - geometric mean $\mathrm{C}_{\mathrm{T}}$ of 3 reference genes (Livak and Schmittgen, 2001).

\section{Oil Red O Staining and Lipid Quantification}

Cells were fixed in $10 \%$ formaldehyde for $30 \mathrm{~min}$ and washed with PBS and subsequently stained with oil red $\mathrm{O}$ for $10 \mathrm{~min}$. The stained adipocytes were photographed with an optical microscope at $200 \times$ and $400 \times$ magnifications. Oil red $\mathrm{O}$ dye was dissolved in isopropanol, and lipids were quantified by a microplate reader (BioTek, Winooski, VT) at $518 \mathrm{~nm}$ (Mehlem et al., 2013).

\section{Statistical Analysis}

Data were analyzed as a completely random design using PROC MIXED model of SAS 9.4 (SAS Institute Inc., Cary, NC). In the dose-dependent study, concen- tration of each FA was considered as the fixed factor, and replicate was considered as a random factor. For comparison of specific FA, FA was a fixed factor, and replicate was considered as a random factor. Data were reported as least squares means with standard error. Statistical significance was declared at $P<0.05$.

\section{RESULTS}

\section{SVC Isolation and Adipogenic Induction}

The SVC and induced preadipocytes resembled fibroblasts, and lipid droplets were not observed in the cytosol during the commitment stage (Figure 1). In the maturation stage, the preadipocytes were differentiated into mature adipocytes, which were characterized by the appearance of lipids in the cytosol and an oval shape.

\section{Dose-Dependent Effects on Adipogenesis}

To determine an appropriate concentration of FA in incubation mediums for bovine adipocyte adipogenesis, the dose-dependent effects were studied. When mature adipocytes were induced in medium with 150 or 250

\section{SVC without induction $(100 \times)$}

$1 \mathrm{~d}$

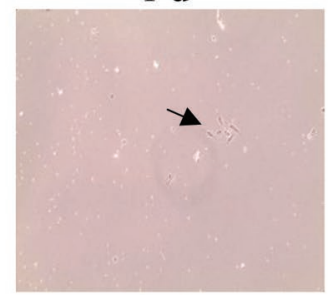

$1 \mathrm{~d}$

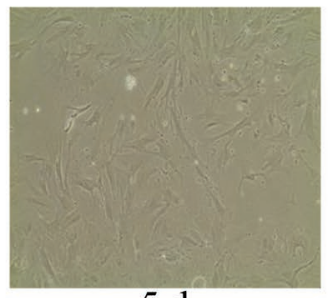

$5 \mathrm{~d}$

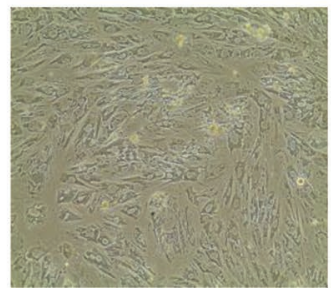

$3 \mathrm{~d}$

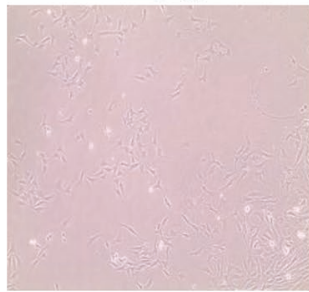

$2 \mathrm{~d}$

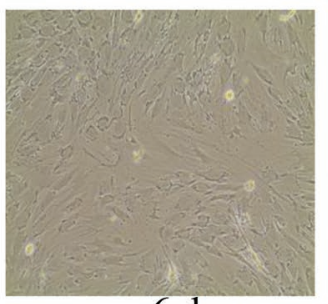

$6 d$

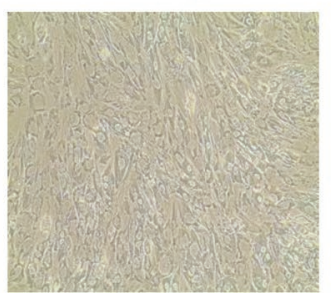

$5 \mathrm{~d}$

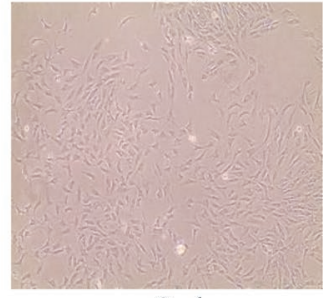

$3 \mathrm{~d}$

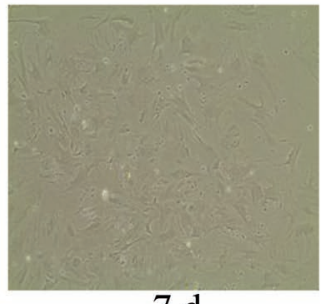

$7 \mathrm{~d}$

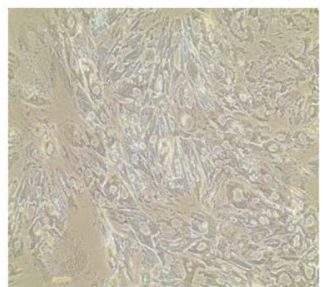

Figure 1. Proliferation and adipogenic induction of bovine stromal vascular cells (SVC) without supplementing fatty acids. The arrow indicates the observed SVC. Color version available online. 
Table 1. Effects of increasing amounts of myristic, palmitic, stearic, oleic, and linoleic acids on contents of lipids in adipocytes measured by quantification of oil red $\mathrm{O}$ staining

\begin{tabular}{|c|c|c|c|c|c|c|}
\hline \multirow{2}{*}{$\begin{array}{l}\text { Item }^{1} \\
\text { (absorbance at } 508 \mathrm{~nm} \text { ) }\end{array}$} & \multicolumn{4}{|c|}{ Concentration of fatty acids $(\mu M)$} & \multirow[b]{2}{*}{ SEM } & \multirow[b]{2}{*}{$P$-value } \\
\hline & Control & $150 / 50$ & $250 / 100$ & $300 / 150$ & & \\
\hline Myristic acid & $0.81^{\mathrm{a}}$ & $1.47^{\mathrm{b}}$ & $1.33^{\mathrm{b}}$ & $0.94^{\mathrm{a}}$ & 0.127 & $<0.0001$ \\
\hline Palmitic acid & $0.42^{\mathrm{a}}$ & $0.51^{\mathrm{b}}$ & $0.51^{\mathrm{b}}$ & $0.33^{\mathrm{c}}$ & 0.009 & $<0.0001$ \\
\hline Stearic acid & $0.38^{\mathrm{a}}$ & $0.46^{\mathrm{b}}$ & $0.62^{\mathrm{c}}$ & $0.14^{\mathrm{d}}$ & 0.026 & $<0.0001$ \\
\hline Oleic acid & $0.35^{\mathrm{a}}$ & $0.84^{\mathrm{b}}$ & $0.91^{\mathrm{b}}$ & $0.64^{\mathrm{c}}$ & 0.024 & $<0.0001$ \\
\hline Linoleic acid & $0.49^{\mathrm{a}}$ & $0.91^{\mathrm{b}}$ & $1.14^{\mathrm{c}}$ & $1.27^{\mathrm{d}}$ & 0.029 & $<0.0001$ \\
\hline
\end{tabular}

$\mu M$ myristic, palmitic, or oleic acids, the content of lipids in cytosol was greater than other concentrations of these same FA (Table 1). When the concentrations of stearic and linoleic acids were, respectively, at 100 and $300 \mu M$, the mature adipocytes had the greatest content of lipids compared with other concentrations.

For SFA, the contents of lipids in mature adipocytes induced in a medium containing $300 \mu M$ palmitic or myristic acid, or $150 \mu M$ stearic acid were greatly reduced, and the contents were similar or even less than control (Table 1). The microscopic evaluation indicated that the cell confluence was greatly decreased under these concentrations of FA, suggesting the detrimental effects of the doses on cell survival (Supplemental Figure S1; https://doi.org/10.3168/jds.2017-13312).

To further investigate the dose effects of FA on adipogenesis, the mRNA expressions of several adipogenic $(P P A R G, F A B P 4)$ and lipogenic $(A C C 1, F A S N)$ genes in mature adipocytes were analyzed (Figure 2). When SVC were treated with $250 \mu M$ myristic acid, the mRNA expressions of PPARG and FABP4 in mature adipocytes were greater than other concentrations. Compared with control, 150 and $250 \mu M$ myristic acid inhibited the transcription of $A C C 1$. However, the transcription at $300 \mu M$ myristic acid was greater than at 150 and $250 \mu M$. For $F A S N$, mRNA expression was not affected by the dose of myristic acid.

The mRNA expressions of PPARG and FABP 4 were greater at $250 \mu M$ palmitic acid than at other concentrations (Figure 2). For $A C C 1$, the mRNA expression was greater at $300 \mu M$ than at other concentrations. Compared with control, the mRNA expression of FASN was inhibited by palmitic acid, and the expression at $300 \mu M$ was greater than at 150 and $250 \mu M$.

The mRNA expression of PPARG was not affected by stearic acid (Figure 2). The mRNA abundance of $F A B P 4$ and FASN at $100 \mu M$ was greater than at other concentrations. The mRNA abundance of $A C C 1$ was inhibited by stearic acid compared with control.
The mRNA expression of PPARG was upregulated in a dose-dependent manner by oleic acid with greater expression at 250 and $300 \mu M$ than in a medium without or with $150 \mu M$ oleic acid (Figure 2). The mRNA abundances of $F A B P 4, A C C 1$, and $F A S N$ were greater at $250 \mu M$ than at other concentrations.

Linoleic acid upregulated mRNA expressions of $P P A R G$ and $A C C 1$ that expressions were greater at 250 and $300 \mu M$ (Figure 2). For FABP4, the mRNA abundance at $300 \mu M$ was greater than the medium without or with $150 \mu M$, and similar with $250 \mu M$. At $300 \mu M$, the mRNA expression of FASN was greater than other concentrations.

\section{Commitment Stage and Treatment by FA}

Adipogenesis is categorized into an adipogenic commitment stage and a maturation stage. Because the 2 stages are regulated by different transcriptional cascades, the bovine adipocytes undergoing adipogenesis were treated by long-chain FA in the commitment stage and maturation stage.

Compared with the control, the number of differentiated mature adipocytes was increased when the commitment stage was treated with oleic and linoleic acids, but the number was not affected by other FA (Figure 3 ). Content of lipids in the culture medium was greater for SVC treated with FA compared with control (Figure 3). In addition, the content of lipids was different between FA treatments in the order from maximum to minimum of oleic, linoleic, myristic, palmitic, and stearic acids.

Because the adipocyte number was affected by FA in the commitment stage, several preadipogenic genes controlling the adipogenic lineage were analyzed on $\mathrm{d}$ 4 of adipogenesis. The mRNA expressions of $C E B P D$, FOXA2, and ZFP423 were upregulated by oleic and linoleic acids compared with the control, but the expressions were not affected by other FA (Figure 4). 
The expression of $P D G F A$ was upregulated by linoleic acid but was not affected by other FA. Compared with control, the expression of Klf5 was not affected by FA.

Fully differentiated mature adipocytes contained different lipids, so the genes controlling the lipogenesis were analyzed on $\mathrm{d} 8$ in adipogenesis. The mRNA expressions of transcriptional factors $P P A R G$ and $C E B P A$ in mature adipocytes were downregulated in mature adipocytes treated by oleic and linoleic acids in the commitment stage, and the expression of SREBPA was not affected by FA compared with control (Figure 5). In de novo FA synthesis, the expression of $A C C 1$ was downregulated and $F A S N$ was not affected by linoleic acid compared with control. In lipolysis, the expression of $H S L$ was downregulated by linoleic acid, and $A T G L$ was downregulated by palmitic, stearic, and linoleic
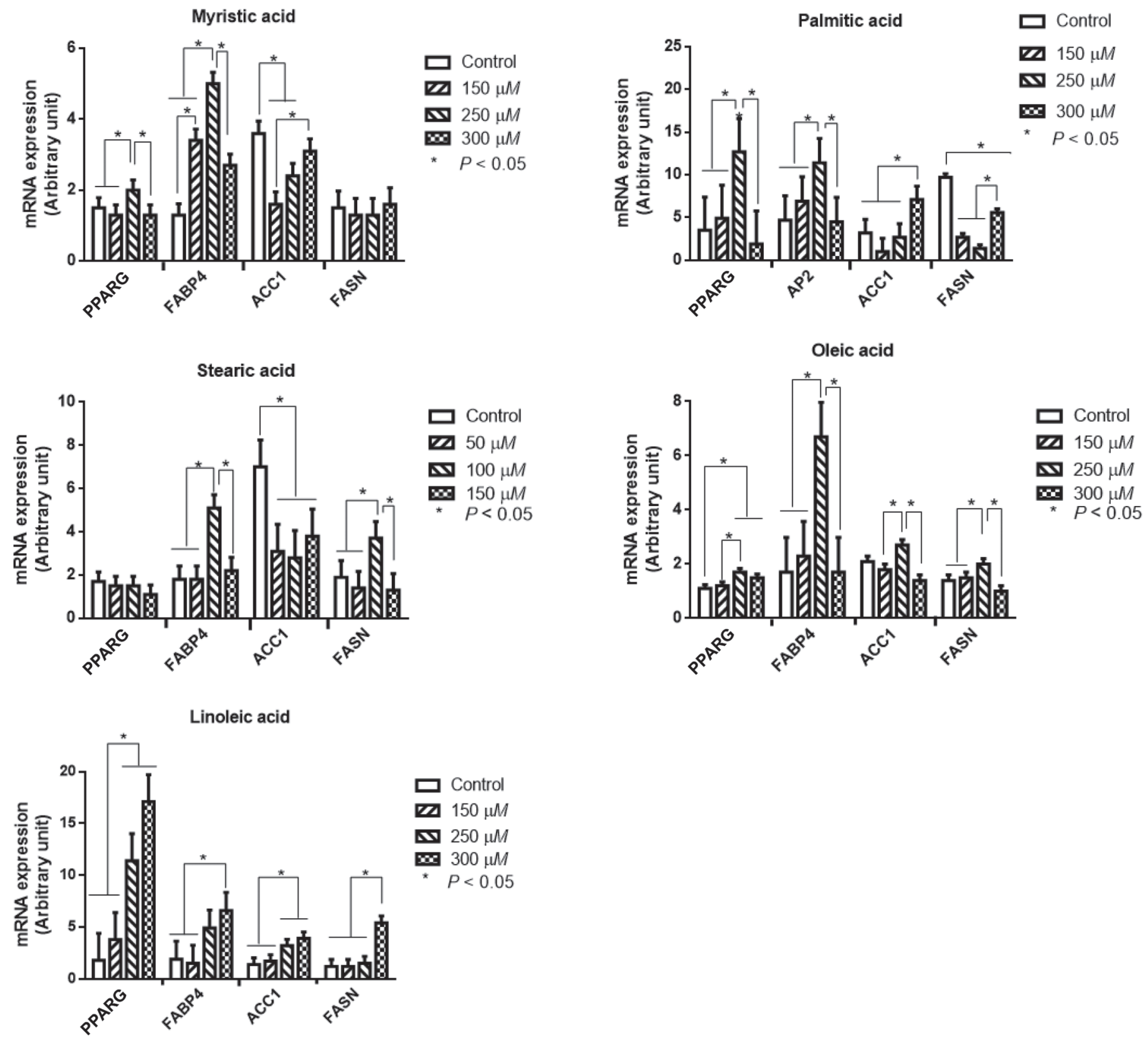

Figure 2. Effects of concentrations of long-chain fatty acids on gene expressions in mature adipocytes. Results were shown by mean \pm SEM; $* P<0.05$. PPARG = peroxisome proliferator activated receptor gamma; FABP4 = fatty acid binding protein $4 ; A C C 1=$ acetyl-CoA carboxylase $1 ; F A S N=$ fatty acid synthase. 

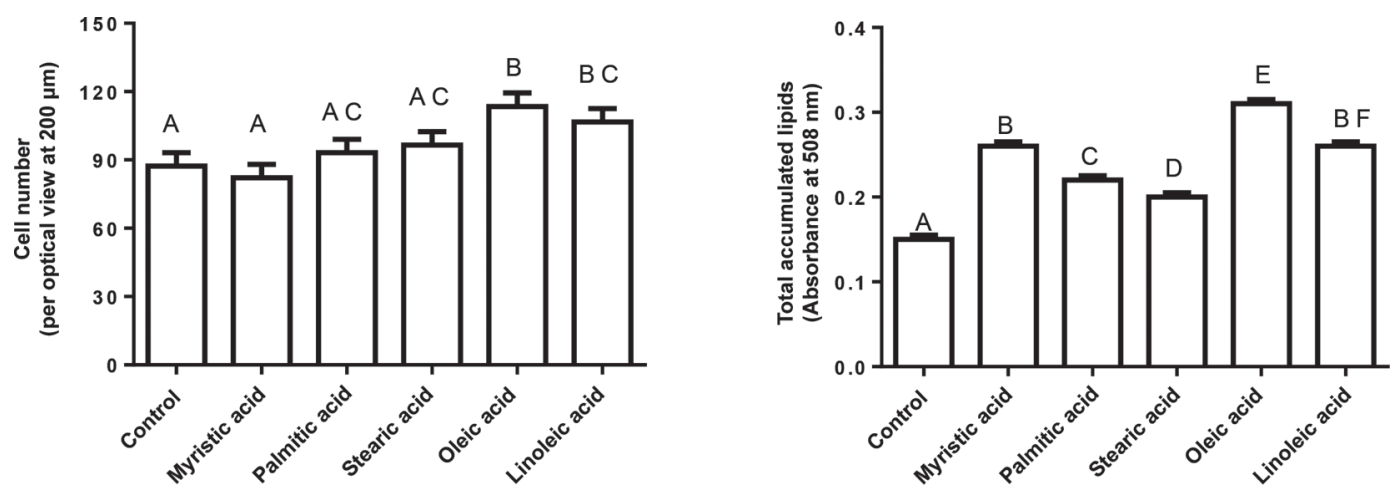

Figure 3. Cell number and accumulated lipids of mature adipocytes when commitment stage was treated with long-chain fatty acids. Results are shown as mean \pm SEM. For treatments with the same letter, the difference between means is not statistically significant $(P \geq 0.05)$.

acids compared with control. The glucose transporter GLUT4 was downregulated by oleic and linoleic acids, and the FA binding protein $F A B P 4$ was not affected by FA. For leptin, the expression was downregulated by stearic, oleic, and linoleic acids compared with control.

\section{Maturation Stage and Treatment by FA}

The number of mature adipocytes was not affected by the FA supplemented in the maturation stage (Figure 6). Except for palmitic acid, other FA treatments greatly increased the total accumulated lipids in the medium compared with control, and the FA order from maximum to minimum content of lipids was oleic, linoleic, myristic, stearic, and palmitic acids (Figure 6).

When the maturation stage was treated with FA, SFA upregulated the mRNA expressions of $P P A R G$ and $C E B P A$ compared with control in mature adipocytes (Figure 7). Oleic acid upregulated expression of $P P A R G$ and did not affect $C E B P A$. Compared with control, the expressions of PPARG and CEBPA were not affected by linoleic acid. The SREBPA was upregulated by stearic acid and was not affected by other FA. In de novo FA synthesis, the mRNA abundances of $A C C 1$ and $F A S N$ were downregulated by linoleic acid, and $F A S N$ was upregulated by oleic acid. The expressions of $A C C 1$ and $F A S N$ were not affected by SFA. In lipolysis, $H S L$ was upregulated by myristic, stearic, and linoleic acids, and was not affected by palmitic and oleic acids. The expression of $A T G L$ was not affected by FA. The glucose transporter GLUT4 was upregulated by UFA, but was not affected by SFA. The FA binding protein $F A B P 4$ was upregulated by myristic acid and was not affected by other FA. For leptin, the gene expression was upregulated by myristic, oleic, and linoleic acids, and was not affected by palmitic and stearic acids.

\section{DISCUSSION}

\section{Dose-Dependent Effects on Adipogenesis}

Cell Survival. When SVC were differentiated to mature adipocytes, these cells were less tolerant to high concentrations of SFA compared with UFA. Especially for stearic acid, cells died in a relatively low concentration $(150 \mu M)$ during incubation. Compared with SFA, the cell survival was not affected by UFA, even when the concentration was up to $300 \mu M$. Similar to this study, when human granulosa cells were treated with palmitic and stearic acids, cell death was observed and displayed in a dose-dependent response $(\mathrm{Mu}$ et al., 2001). However, cell survival was not affected by the same concentrations of PUFA, even in supraphysiological concentrations. When rat $\beta$ islet cells were treated with palmitic acid, the cellular concentration of ceramide increased along with a decreased cell number (Shimabukuro et al., 1998). Ceramide is an important signal triggering apoptosis, and the long-chain SFA are substrates for de novo ceramide synthesis (Taha et al., 2006). The toxic effects of SFA on adipogenesis may be associated with ceramide synthesis though the content was not analyzed in this study.

Adipogenic Genes. The nuclear receptor PPARG is a master transcriptional regulator in adipogenesis and lipogenesis (Rosen and MacDougald, 2006). In gain and loss function studies, PPARG knockout animals fail to generate adipose tissue, whereas activation of PPARG by agonists can greatly enhance adipogenesis (Kletzien et al., 1992; Jones et al., 2005). Fatty acids, especially UFA, have been identified as natural ligands to activate the expression and activity of $P P A R G$, and increase adipogenesis (Rosen et al., 2000). However, in bovine mammary gland epithelial cells, long-chain FA diversely affect the expression of $P P A R G$ and the expression is activated by palmitic and stearic acids, 
and inhibited by UFA, such as oleic acid and C18:1 trans-10 (Kadegowda et al., 2009b). In our study, the expression of PPARG was activated in adipocytes in a dose-dependent manner by myristic and palmitic acids, which was similar with effects observed in mammary gland cells. However, the expression of PPARG was also upregulated by oleic and linoleic acids in adipocytes, which was different than observed with mammary gland cells. The genes ACC1 and FASN encode the rate-limiting enzymes in de novo FA synthesis, and were observed to be upregulated by doses of oleic and linoleic acids in adipocytes. The observation was consis-
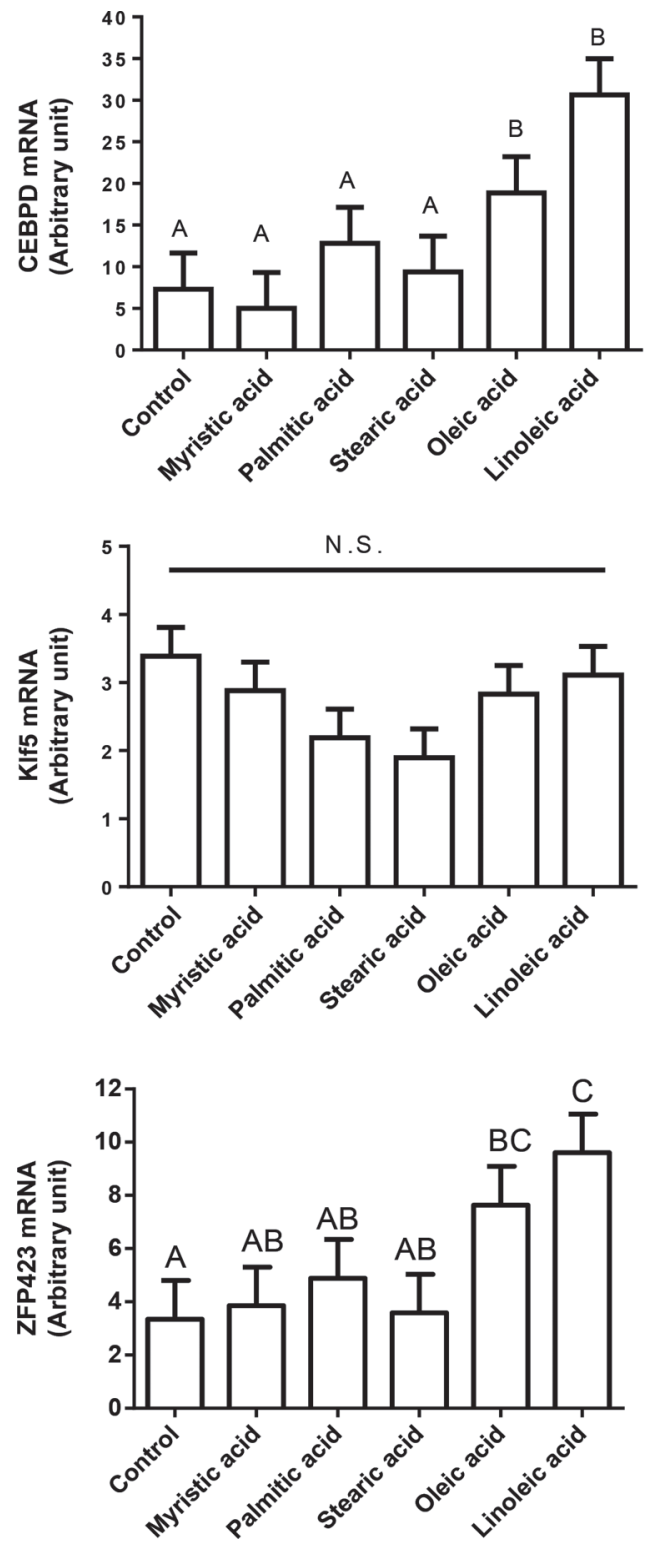

tent with previous studies of Schmitt et al. (2011) and Vahmani et al. (2014) who supplemented UFA to dairy cows and observed the increased expressions of $A C C 1$ and FASN in adipose tissues. In milk fat synthesis, milk fat depression usually happens when cows are fed UFA (Palmquist et al., 1993; Giesy et al., 2002). Especially, partial biohydrogenation of linoleic acid produces C18:2 trans-10,cis-12 in the rumen (Chilliard et al., 2007). C18:2 trans-10, cis-12 is an important precursor to inhibit milk fat synthesis (Bauman et al., 2008). When C18:2 trans-10, cis-12 are infused into the abomasum or vein, milk fat depression is caused by downregulating
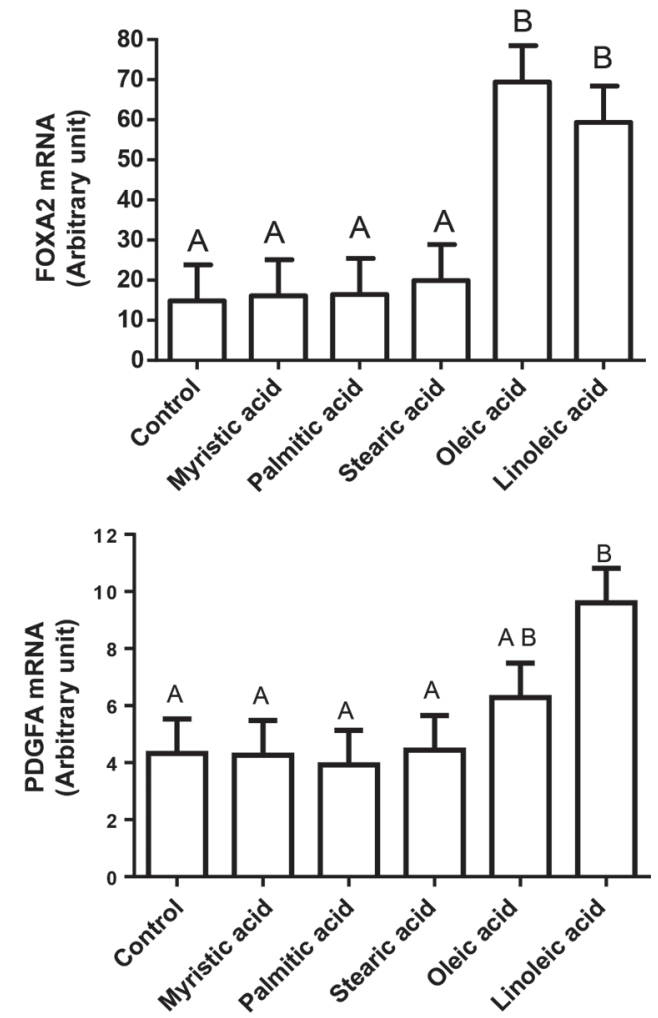

Figure 4. Effects of long-chain fatty acids on mRNA expressions of preadipogenic genes in the commitment stage. Results are shown as mean \pm SEM. For treatments with the same letter, the difference between means is not statistically significant $(P \geq 0.05)$. CEBPD $=$ CCAAT/ enhanced binding protein delta; FOXA2 = forkhead box protein A2; KLF5 = Kruppel like factor 5; PDGFA = platelet derived growth factor alpha; ZFP423 = zinc figure protein 423. 
the expressions of adipogenic genes in the mammary gland, including FASN, ACC1, SREBP1c, and PPARG (Gervais et al., 2009; Harvatine et al., 2009). However, at the same time, the milk fat depression from C18:2 trans-10,cis-12 is accompanied by enhanced lipogenesis in adipose tissue through upregulating these genes (Harvatine et al., 2009). Similar with C18:2 trans-10,cis-12, this study suggested that oleic and linoleic acids may likely facilitate more dietary nutrients partitioned to adipose tissue rather than the mammary gland through regulation of $P P A R G, F A S N$, and $A C C 1$.

The FABP4 is a FA transporter, shuttling hydrophobic long-chain FA from extracellular fluid to target organelles (Besnard et al., 2002). Enhanced adipogen-
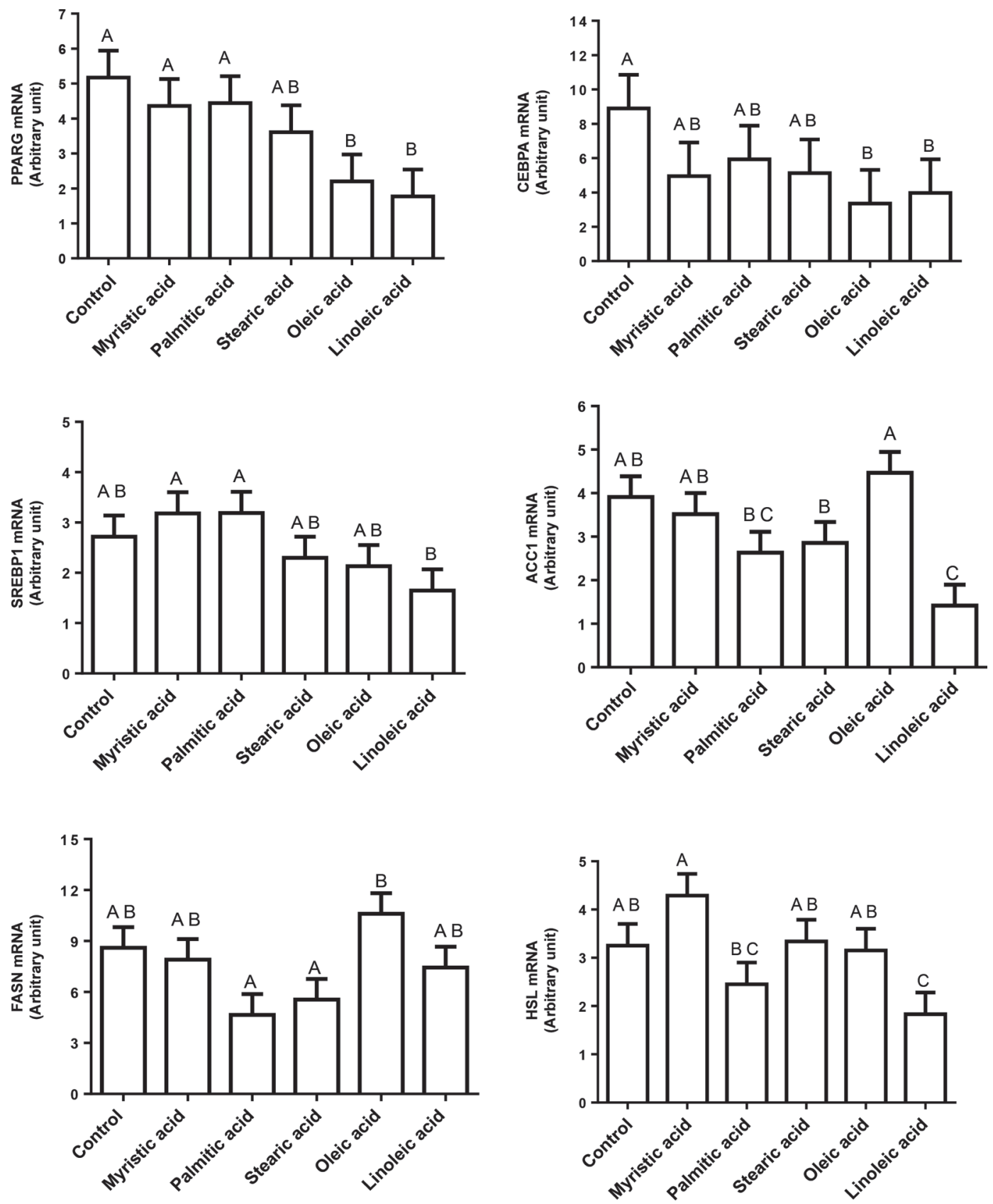

Figure 4 (Continued). Effects of long-chain fatty acids on mRNA expressions of preadipogenic genes in the commitment stage. Results are shown as mean \pm SEM. For treatments with the same letter, the difference between means is not statistically significant $(P>0.05)$. $C E B P D=$ CCAAT/enhanced binding protein delta; FOXA2 = forkhead box protein A2; KLF5 = Kruppel like factor 5; PDGFA = platelet derived growth factor alpha; $Z F P 423=$ zinc figure protein 423 

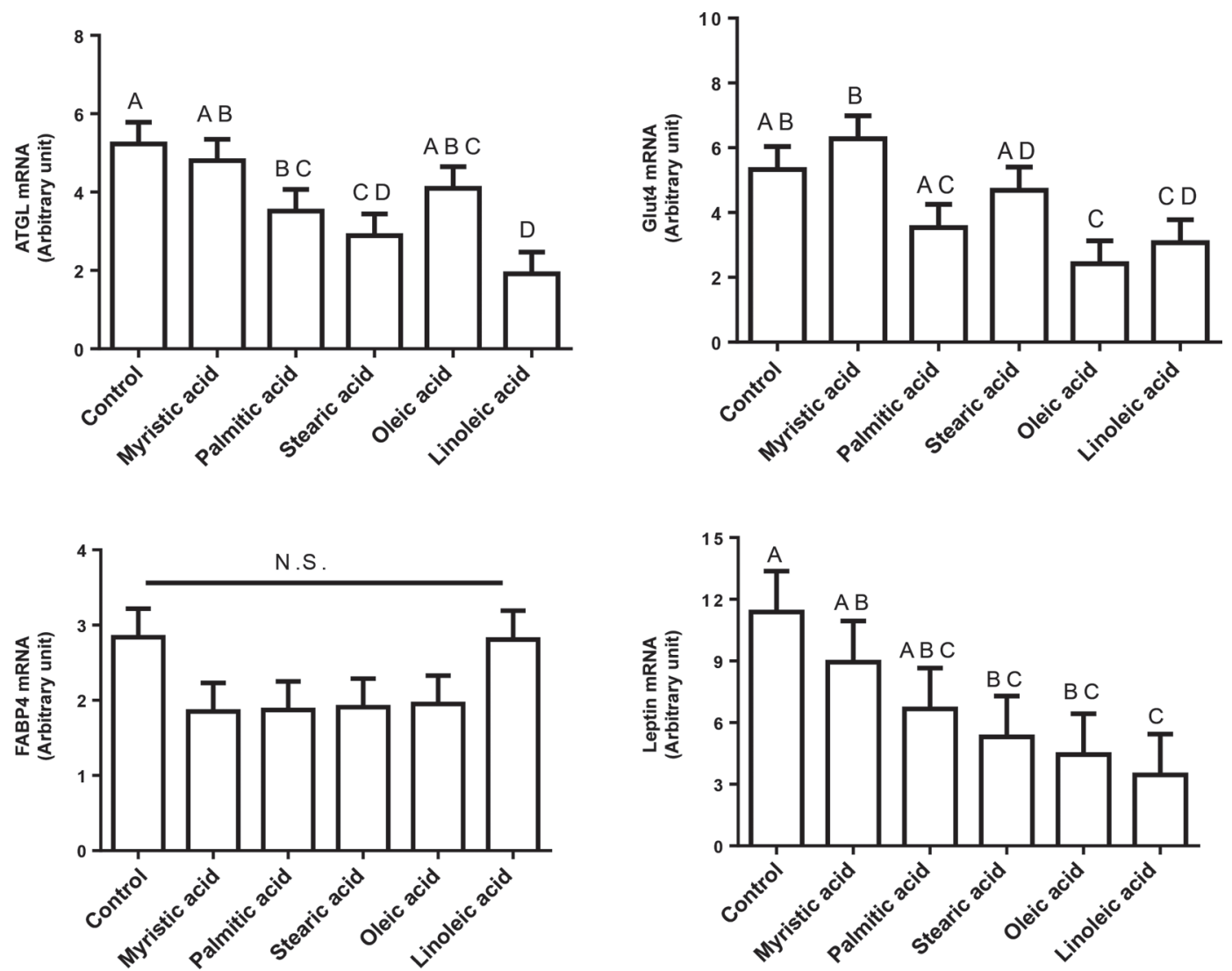

Figure 5. mRNA expressions of adipogenic and lipogenic genes in mature adipocytes when the commitment stage was treated with longchain fatty acids. Results are shown as mean \pm SEM. For treatments with the same letter, the difference between means is not statistically significant $(P \geq 0.05)$. ATGL = triacylglycerol lipase; GLUT4 = glucose transporter $4 ; F A B P 4=$ fatty acid binding protein 4.

esis and lipogenesis are generally correlated with the increased expression of FABP 4 (Tontonoz et al., 1994a; Moseti et al., 2016). FABP 4 is also a downstream effector of PPARG, and PPARG can bind to the promoter of
FABP 4 to activate the expression (Rosen et al., 2000). Therefore, the expression of FABP\& was observed to be tightly associated with $P P A R G$ in this study (Figure 7). However, the transcription of $F A B P 4$ was increased,
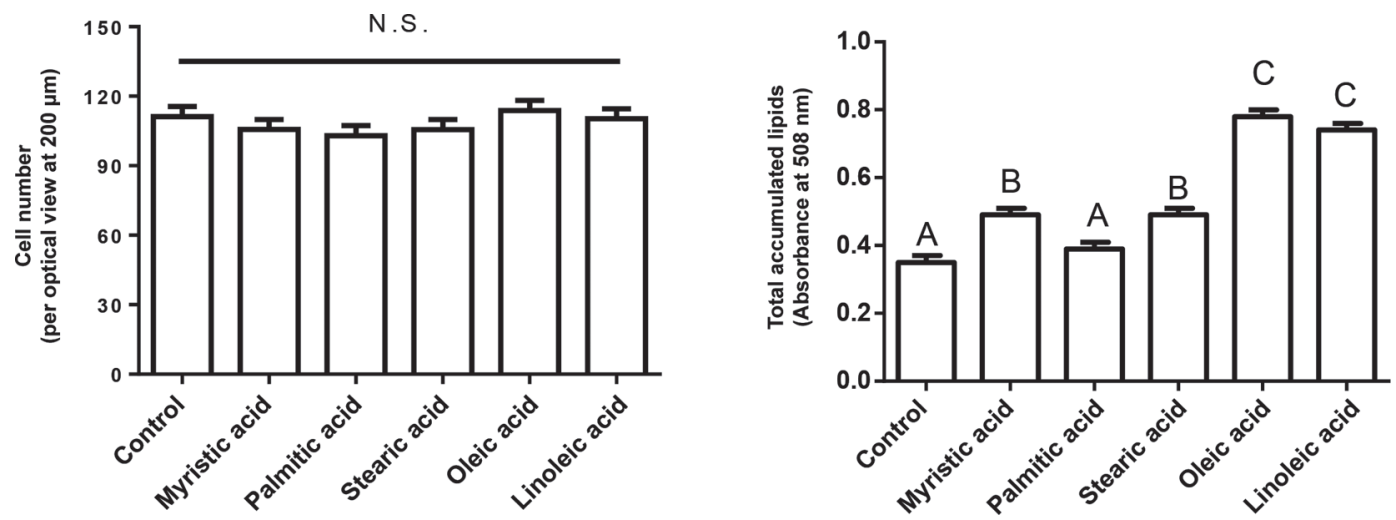

Figure 6. Adipocyte number and accumulated lipids of mature adipocytes affected by long-chain fatty acids treated in the maturation stage. Results are shown as mean \pm SEM; NS: $P \geq 0.05$. For treatments with the same letter, the difference between means is not statistically significant $(P \geq 0.05)$. 
whereas PPARG was not affected by stearic acid, indicating that there were other mechanisms where stearic acid positively regulates $F A B P$ \& without affecting PPARG.

In this study, when adipocytes were induced by increased concentrations of myristic and palmitic acids $(<300 \mu M)$, de novo FA synthesis was inhibited by downregulating $A C C 1$ and $F A S N$. In mammary gland cells, Qi et al. (2014) reported that mRNA expressions of $A C C 1$ and FASN were inhibited by the dose of palmitic and stearic acids. However, in adipocytes, stearic acid only inhibited the initial step (ACC1) of de novo FA synthesis while stimulating the elongation step $(F A S N)$. This is consistent with the decreased average expression of $A C C 1$ and increased expression of FASN in adipose tissue when Thering et al. (2009b) fed rumen inert stearic acid to dairy cows. Phosphorylation activated by kinases, such as AMP-activated protein kinase and protein kinase A, may also be involved in the regulation of $A C C 1$ (Peng et al., 2012).

Appropriate Dose of FA for Optimal Adipogenesis. Establishing an appropriate dose of each FA for adipogenesis is essential to evaluate dose-dependent effects of FA on each stage of adipogenesis. Integrating the results from cell survival, lipid formation, and gene expressions, adipogenesis was optimal at $250 \mu M$ myristic, palmitic, and oleic acids. For stearic acid and linoleic acid, the concentrations for optimal adipogenesis were at 100 and $300 \mu M$, respectively.

\section{Effect of FA on Commitment Stage}

An increase in mass of adipose tissue can be from an upsurge of adipocyte number, size, or both (Arner et al., 2010). Increasing adipocyte number enhances adipose tissue's potential to store lipids, which will reduce the excess of peripheral circulated NEFA (Kim et al., 2014). Therefore, enhancing adipogenic commitment is beneficial to increase the glucose sensitivity and attenuate the local inflammation and metabolic syndromes of obese cows (Bobe et al., 2004; Rico et al., 2015).

Effects of FA on Adipogenic Commitment. In this study, the adipocyte number was increased by oleic and linoleic acids. The adipocyte number is determined by an adipogenic lineage of progenitor cells in the commitment stage (Rosen and MacDougald, 2006). In the commitment stage, the expressions of $c E B P D, Z F P 423$ were upregulated by oleic and linoleic acids. $C E B P D$ is expressed earlier than PPARG and $C E B P A$ in adipogenesis, and ectopic expression of $C E B P D$ can induce the expression of $P P A R G$ and $C E B P A$ in progenitor cells and initiate an adipogenic program (Wu et al., 1996). In addition, transcription factor ZFP423 is able to bind the promoter of PPARG and activate the gene expression (Gupta et al., 2010; Huang et al., 2012). ZFP423 has been considered as a master transcriptional factor in determining adipogenic lineage in the commitment stage (Gupta et al., 2010). Therefore, the increased adipocyte number from oleic and linoleic acids may result from the enhanced adipogenic lineage through activations of $\mathrm{c} / \mathrm{EBPB}$ and ZFP423 in the commitment stage. PDGFA can reflect the state of adipogenic commitment and is often used to select the adipogenic progenitor cells in flow cytometry (Lee et al., 2012). That was consistent with the result that expression was upregulated by linoleic acid. Although the expression of PDGFA was not significantly increased by oleic acid, the average was greater than control and other FA. Another transcriptional factor FOXA2 was also activated by oleic and linoleic acid in the study. The transcription factor FOXA2 was previously observed to be upregulated in obese mice (Wolfrum et al., 2003). The adipogenic genes expressed in later stages of adipogenesis are generally inhibited by FOXA2, but its role in the early stage of adipogenesis has not been well defined (Davis et al., 2004). This study indicated that FOXA2 may bivalently affect adipogenesis.

Mature Adipocytes Affected by FA in the Commitment Stage. Except for FASN and FABP 4 , the adipogenic genes encoding key transcriptional factors (PPARG, CEBPA), lipogenesis and lipolysis enzymes $(A C C 1, H S L, A T G L)$, and the glucose transporter GLUT4 were all downregulated in mature adipocytes when the commitment stage was treated with oleic or linoleic acid. Because normalized gene expression is based on the mRNA abundance per cell (Kanno et al., 2006), less expression of adipogenic genes could be due to the smaller size of the adipocytes, since in our study the adipocyte number was increased in a limited space. This was consistent with the reduced expression of leptin in adipocytes treated with oleic and linoleic acids since leptin excretion is usually positively correlated with the adipocyte size (Harris, 2014).

\section{Effects of FA on the Maturation Stage}

Lipogenesis Affected by FA. Long-chain FA are known to diversely affect lipogenesis in bovine mammary gland cells and hepatic cells (Bionaz et al., 2008; Kadegowda et al., 2009a; Thering et al., 2009a). Lactation performance and BW are variably affected by feeding different long-chain FA to dairy cows (Loften et al., 2014). In this study, we further investigated the 
specific FA on lipogenesis in adipocytes. When maturation stage was treated with long-chain FA, the lipid synthesis in adipocytes was preferentially enhanced by oleic and linoleic acids more than other FA.

When considering SFA, mature adipocytes synthesized more lipids when they were exposed to stearic or myristic acids, than when exposed to palmitic acid in the study. Enjalbert et al. (1998, 2000) infused the same amounts of stearic and palmitic acids to the duodenum, and observed a less quantity of infused stearic acid transferred into milk compared with palmitic acid. This indicated that the mammary gland may preferentially use palmitic acid rather than stearic acid for milk fat synthesis, and adipose tissue may preferentially use stearic acid rather than palmitic acid for lipogenesis (Loften et al., 2014).

Lipogenic Genes Affected by FA. When the maturation stage of adipocytes was treated with longchain FA, the master adipogenic regulators PPARG and $C E B P A$ were all upregulated. The transcriptional factors PPARG and $C E B P A$ are 2 principal adipogenic regulators in adipogenesis and facilitate preadipocytes in establishing biological functions of adipocytes, such as insulin sensitivity, FA uptake, and triacylglycerol synthesis (Rosen and MacDougald, 2006). Because UFA, especially n-3 and n-6-PUFA, are found to have a greater potency to bind PPARG and activate its activity and expression than SFA, adipogenesis in adipocytes is much more enhanced by UFA than SFA (Varga et al., 2011). The master adipogenic gene SREBP1c was not significantly affected by long-chain FA, but the average was much greater than control. Therefore, FA may regulate the expression of lipogenic genes to alter lipid accumulation in adipocytes. The increased expression of leptin by FA was consistent with the increased lipid content in adipocytes (Harris, 2014). However, in this study, the expression of $P P A R G$ was less affected by linoleic acid. Coinciding with $P P A R G$, the de novo FA
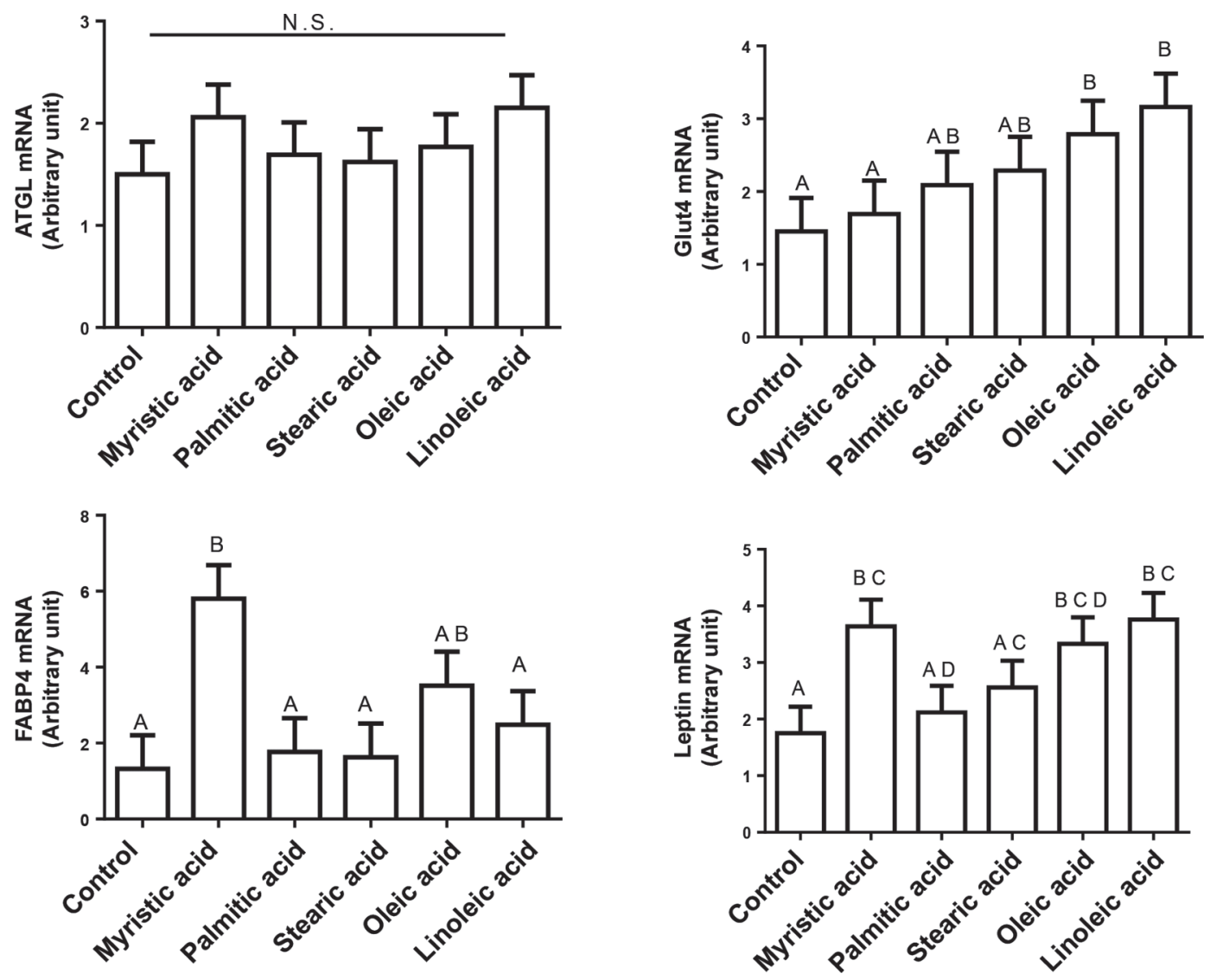

Figure 7. mRNA expressions of adipogenic genes in mature adipocytes when the maturation stage was treated with long-chain fatty acids. Results are shown as mean \pm SEM. For treatments with the same letter, the difference between means is not statistically significant $(P \geq 0.05)$. $P P A R G=$ peroxisome proliferator activated receptor gamma; $C E B P A=\mathrm{CCAAT} /$ enhanced binding protein alpha; $S R E B P 1 c=$ sterol regulatory element binding protein $1 \mathrm{c} ; A C C 1=$ acetyl-CoA carboxylase $1 ; F A S N=$ fatty acid synthase; $H S L=$ hormone sensitive lipase; $A T G L=$ triacylglycerol lipase; GLUT4 = glucose transporter $4 ; F A B P 4=$ fatty acid binding protein 4. 
synthesis ( $A C C 1$ and $F A S N$ ) was inhibited by linoleic acid.

\section{CONCLUSIONS}

Adipogenesis and lipogenesis are important physiological processes to shape the phenotype of adipose tissue, potentially affecting the milk performance and health of dairy cattle. Our studies indicated that the commitment and maturation stages of bovine adipocytes in adipogenesis were variably affected by longchain FA and dependent on dose and type. When concentrations of FA were greater than in vivo, SFA were more toxic to cell survival than UFA in adipogenesis.
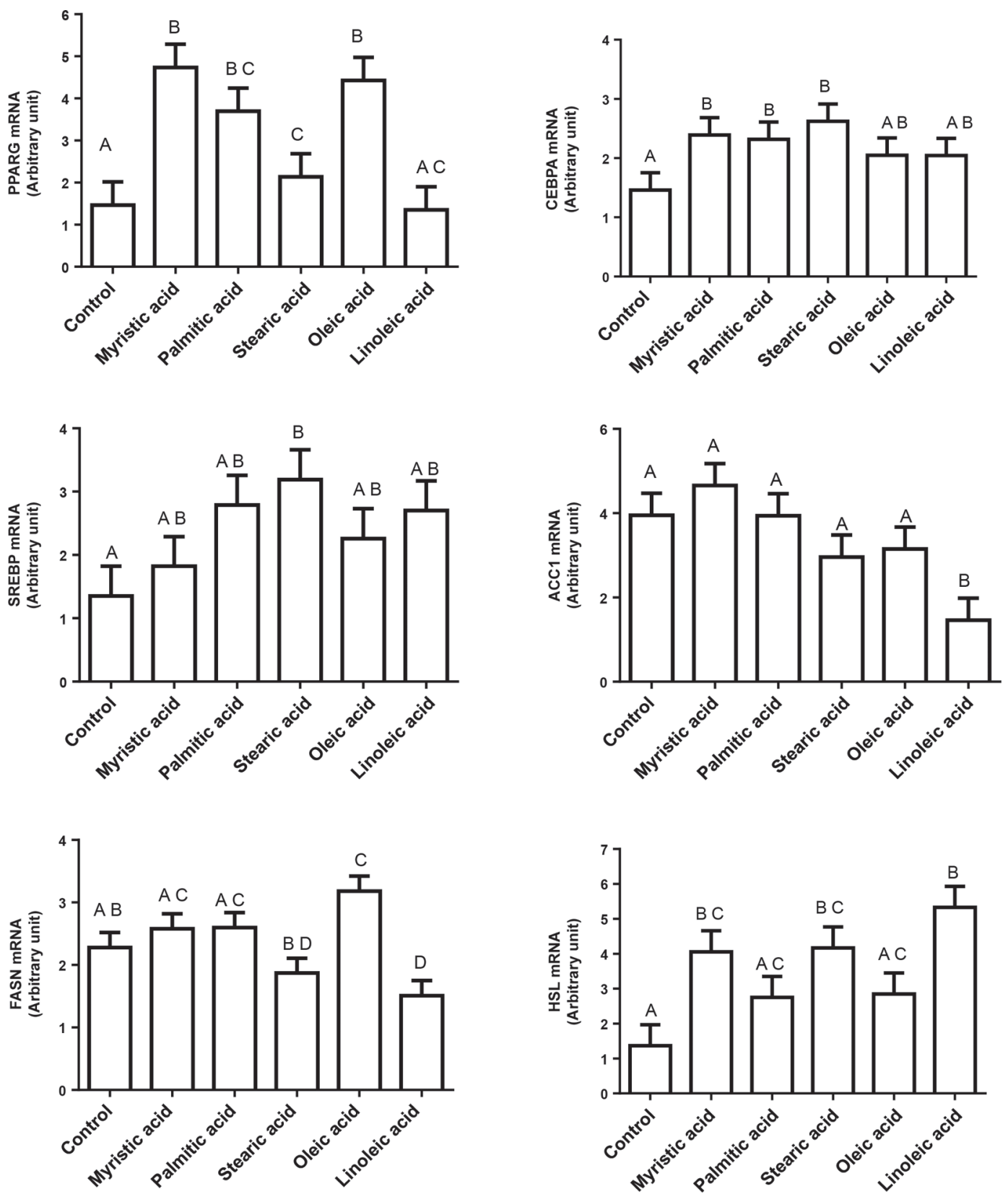

Figure 7 (Continued). mRNA expressions of adipogenic genes in mature adipocytes when the maturation stage was treated with long-chain fatty acids. Results are shown as mean \pm SEM. For treatments with the same letter, the difference between means is not statistically significant $(P \geq 0.05) . P P A R G=$ peroxisome proliferator activated receptor gamma; $C E B P A=$ CCAAT $/$ enhanced binding protein alpha; $S R E B P 1 c=$ sterol regulatory element binding protein $1 \mathrm{c} ; A C C 1=$ acetyl-CoA carboxylase $1 ; F A S N=$ fatty acid synthase; $H S L=$ hormone sensitive lipase; $A T G L=$ triacylglycerol lipase; GLUT4 $=$ glucose transporter $4 ; F A B P 4=$ fatty acid binding protein 4. 
Oleic and linoleic acids increased adipocyte number and size through enhancing adipogenic commitment and lipogenesis. The adipogenic commitment was not affected by SFA, but lipogenesis was much more enhanced by myristic and stearic acids than palmitic acid.

\section{ACKNOWLEDGMENTS}

Financial support for the conduct of this research was provided by Arm and Hammer Animal Nutrition (Princeton, NJ).

\section{REFERENCES}

Arner, E., P. O. Westermark, K. L. Spalding, T. Britton, M. Rydén, J. Frisén, S. Bernard, and P. Arner. 2010. Adipocyte turnover: Relevance to human adipose tissue morphology. Diabetes 59:105-109. https://doi.org/10.2337/db09-0942.

Bauman, D. E., J. W. Perfield, K. J. Harvatine, and L. H. Baumgard 2008. Regulation of fat synthesis by conjugated linoleic acid: Lactation and the ruminant model. J. Nutr. 138:403-409.

Besnard, P., I. Niot, H. Poirier, L. Clément, and A. Bernard. 2002. New insights into the fatty acid-binding protein (FABP) family in the small intestine. Mol. Cell. Biochem. 239:139-147.

Bionaz, M., C. R. Baumrucker, E. Shirk, J. P. Vanden Heuvel, E. Block, and G. A. Varga. 2008. Characterization of Madin-Darby bovine kidney cell line for peroxisome proliferator-activated receptors: temporal response and sensitivity to fatty acids. J. Dairy Sci. 91:2808-2813. https://doi.org/10.3168/jds.2007-0789.

Bobe, G., J. W. Young, and D. C. Beitz. 2004. Invited review: Pathology, etiology, prevention, and treatment of fatty liver in dairy cows. J. Dairy Sci. 87:3105-3124.

Boerman, J. P., J. L. Firkins, N. R. St-Pierre, and A. L. Lock. 2015. Intestinal digestibility of long-chain fatty acids in lactating dairy cows: A meta-analysis and meta-regression. J. Dairy Sci. 98:88898903. https://doi.org/10.3168/jds.2015-9592.

Bonnet, M., L. Bernard, S. Bes, and C. Leroux. 2013. Selection of reference genes for quantitative real-time $\mathrm{PCR}$ normalisation in adipose tissue, muscle, liver and mammary gland from ruminants. Animal 7:1344-1353. https://doi.org/10.1017/S1751731113000475.

Chilliard, Y., F. Glasser, A. Ferlay, L. Bernard, J. Rouel, and M. Doreau. 2007. Diet, rumen biohydrogenation and nutritional quality of cow and goat milk fat. Eur. J. Lipid Sci. Technol. 109:828855. https://doi.org/10.1002/ejlt.200700080.

Davis, K. E., M. Moldes, and S. R. Farmer. 2004. The Forkhead Transcription Factor FoxC2 inhibits white adipocyte differentiation. J. Biol. Chem. 279:42453-42461. https://doi.org/10.1074/jbc .M402197200.

Du, M., Y. Huang, A. K. Das, Q. Yang, M. S. Duarte, M. V. Dodson, and M.-J. Zhu. 2013. Meat Science and Muscle Biology Symposium: Manipulating mesenchymal progenitor cell differentiation to optimize performance and carcass value of beef cattle. J. Anim. Sci. 91:1419-1427. https://doi.org/10.2527/jas.2012-5670.

Du, M., B. Wang, X. Fu, Q. Yang, and M.-J. Zhu. 2015. Fetal programming in meat production. Meat Sci. 109:40-47. https://doi .org/10.1016/j.meatsci.2015.04.010.

Enjalbert, F., M. C. Nicot, C. Bayourthe, and R. Moncoulon. 1998. Duodenal infusions of palmitic, stearic or oleic acids differently affect mammary gland metabolism of fatty acids in lactating dairy cows. J. Nutr. 128:1525-1532.

Enjalbert, F., M. C. Nicot, C. Bayourthe, and R. Moncoulon. 2000. Effects of duodenal infusions of palmitic, stearic, or oleic acids on milk composition and physical properties of butter. J. Dairy Sci. 83:1428-1433. https://doi.org/10.3168/jds.S0022-0302(00)75012 $-0$.
Gervais, R., J. W. McFadden, A. J. Lengi, B. A. Corl, and P. Y. Chouinard. 2009. Effects of intravenous infusion of trans-10, cis-12 18:2 on mammary lipid metabolism in lactating dairy cows. J. Dairy Sci. 92:5167-5177. https://doi.org/10.3168/jds.2009-2281.

Gesta, S., Y.-H. Tseng, and C. R. Kahn. 2007. Developmental origin of fat: Tracking obesity to its source. Cell 131:242-256. https://doi .org/10.1016/j.cell.2007.10.004

Giesy, J. G., M. A. McGuire, B. Shafii, and T. W. Hanson. 2002. Effect of dose of calcium salts of conjugated linoleic acid (CLA) on percentage and fatty acid content of milk fat in midlactation Holstein cows. J. Dairy Sci. 85:2023-2029. https://doi.org/10.3168/ jds.S0022-0302(02)74279-3.

Gupta, R. K., Z. Arany, P. Seale, R. J. Mepani, L. Ye, H. M. Conroe, Y. A. Roby, H. Kulaga, R. R. Reed, and B. M. Spiegelman. 2010. Transcriptional control of preadipocyte determination by Zfp 423 . Nature 464:619-623. https://doi.org/10.1038/nature08816.

Gupta, R. K., R. J. Mepani, S. Kleiner, J. C. Lo, M. J. Khandekar, P. Cohen, A. Frontini, D. C. Bhowmick, L. Ye, S. Cinti, and B. M. Spiegelman. 2012. Zfp423 expression identifies committed preadipocytes and localizes to adipose endothelial and perivascular cells. Cell Metab. 15:230-239. https://doi.org/10.1016/j.cmet.2012 .01 .010 .

Harris, R. B. S. 2014. Direct and indirect effects of leptin on adipocyte metabolism. Biochim. Biophys. Acta 1842:414-423. https://doi .org/10.1016/j.bbadis.2013.05.009.

Harvatine, K. J., J. W. Perfield, and D. E. Bauman. 2009. Expression of enzymes and key regulators of lipid synthesis is upregulated in adipose tissue during CLA-induced milk fat depression in dairy cows. J. Nutr. 139:849-854. https://doi.org/10.3945/jn.108 .099994 .

Huang, Y., A. K. Das, Q.-Y. Yang, M.-J. Zhu, and M. Du. 2012 Zfp423 promotes adipogenic differentiation of bovine stromal vascular cells. PLoS One 7:e47496. https://doi.org/10.1371/journal .pone.0047496.

Jo, J., O. Gavrilova, S. Pack, W. Jou, S. Mullen, A. E. Sumner, S. W. Cushman, and V. Periwal. 2009. Hypertrophy and/or hyperplasia: Dynamics of adipose tissue growth. PLOS Comput. Biol. 5:e1000324. https://doi.org/10.1371/journal.pcbi.1000324.

Jones, J. R., C. Barrick, K.-A. Kim, J. Lindner, B. Blondeau, Y. Fujimoto, M. Shiota, R. A. Kesterson, B. B. Kahn, and M. A. Magnuson. 2005. Deletion of PPARgamma in adipose tissues of mice protects against high fat diet-induced obesity and insulin resistance. Proc. Natl. Acad. Sci. USA 102:6207-6212. https://doi .org/10.1073/pnas.0306743102.

Kadegowda, A. K. G., M. Bionaz, L. S. Piperova, R. A. Erdman, and J. J. Loor. 2009a. Peroxisome proliferator-activated receptorgamma activation and long-chain fatty acids alter lipogenic gene networks in bovine mammary epithelial cells to various extents. J. Dairy Sci. 92:4276-4289. https://doi.org/10.3168/jds.2008-1932.

Kadegowda, A. K. G., M. Bionaz, L. S. Piperova, R. A. Erdman, and J. J. Loor. 2009b. Peroxisome proliferator-activated receptorgamma activation and long-chain fatty acids alter lipogenic gene networks in bovine mammary epithelial cells to various extents. J. Dairy Sci. 92:4276-4289. https://doi.org/10.3168/jds.2008-1932.

Kanno, J., K. Aisaki, K. Igarashi, N. Nakatsu, A. Ono, Y. Kodama, and T. Nagao. 2006. "Per cell" normalization method for mRNA measurement by quantitative PCR and microarrays. BMC Genomics 7:64. https://doi.org/10.1186/1471-2164-7-64.

Kim, S. M., M. Lun, M. Wang, S. E. Senyo, C. Guillermier, P. Patwari, and M. L. Steinhauser. 2014. Loss of white adipose hyperplastic potential is associated with enhanced susceptibility to insulin resistance. Cell Metab. 20:1049-1058. https://doi.org/10.1016/j.cmet .2014.10.010.

Kletzien, R. F., S. D. Clarke, and R. G. Ulrich. 1992. Enhancement of adipocyte differentiation by an insulin-sensitizing agent. Mol. Pharmacol. 41:393-398.

Lee, Y.-H., A. P. Petkova, E. P. Mottillo, and J. G. Granneman. 2012. In vivo identification of bipotential adipocyte progenitors recruited by $\beta 3$-adrenoceptor activation and high-fat feeding. Cell Metab. 15:480-491. https://doi.org/10.1016/j.cmet.2012.03.009. 
Livak, K. J., and T. D. Schmittgen. 2001. Analysis of relative gene expression data using real-time quantitative $\mathrm{PCR}$ and the $2-\Delta \Delta \mathrm{CT}$ method. Methods 25:402-408. https://doi.org/10.1006/meth.2001 .1262 .

Loften, J. R., J. G. Linn, J. K. Drackley, T. C. Jenkins, C. G. Soderholm, and A. F. Kertz. 2014. Invited review: palmitic and stearic acid metabolism in lactating dairy cows. J. Dairy Sci. 97:46614674. https://doi.org/10.3168/jds.2014-7919.

Lowe, C. E., S. O'Rahilly, and J. J. Rochford. 2011. Adipogenesis at a glance. J. Cell Sci. 124:2681-2686. https://doi.org/10.1242/jcs .079699 .

McNamara, J. P., and R. L. Baldwin. 2000. Estimation of parameters describing lipid metabolism in lactation: Challenge of existing knowledge described in a model of metabolism. J. Dairy Sci. 83:128-143. https://doi.org/10.3168/jds.S0022-0302(00)74864-8.

McNamara, J. P., K. Huber, and A. Kenéz. 2016. A dynamic, mechanistic model of metabolism in adipose tissue of lactating dairy cattle. J. Dairy Sci. 99:5649-5661. https://doi.org/10.3168/jds $.2015-9585$.

Mehlem, A., C. E. Hagberg, L. Muhl, U. Eriksson, and A. Falkevall. 2013. Imaging of neutral lipids by oil red $O$ for analyzing the metabolic status in health and disease. Nat. Protoc. 8:1149-1154. https://doi.org/10.1038/nprot.2013.055.

Moseti, D., A. Regassa, and W.-K. Kim. 2016. Molecular regulation of adipogenesis and potential anti-adipogenic bioactive molecules. Int. J. Mol. Sci. 17:E124. https://doi.org/10.3390/ijms17010124.

Mu, Y. M., T. Yanase, Y. Nishi, A. Tanaka, M. Saito, C. H. Jin, C. Mukasa, T. Okabe, M. Nomura, K. Goto, and H. Nawata. 2001. Saturated FFAs, palmitic acid and stearic acid, induce apoptosis in human granulosa cells. Endocrinology 142:3590-3597. https:// doi.org/10.1210/endo.142.8.8293.

Ouchi, N., J. L. Parker, J. J. Lugus, and K. Walsh. 2011. Adipokines in inflammation and metabolic disease. Nat. Rev. Immunol. 11:85-97. https://doi.org/10.1038/nri2921.

Palmquist, D. L., A. D. Beaulieu, and D. M. Barbano. 1993. Feed and animal factors influencing milk fat composition. J. Dairy Sci. 76:1753-1771.

Peng, I.-C., Z. Chen, W. Sun, Y.-S. Li, T. L. Marin, P.-H. Hsu, M.-I. Su, X. Cui, S. Pan, C. Y. Lytle, D. A. Johnson, F. Blaeser, T. Chatila, and J. Y.-J. Shyy. 2012. Glucagon regulates ACC activity in adipocytes through the CAMKK $\beta /$ AMPK pathway. Am. J. Physiol. Endocrinol. Metab. 302:E1560-E1568. https://doi.org/10 .1152/ajpendo.00504.2011.

Qi, L., S. Yan, R. Sheng, Y. Zhao, and X. Guo. 2014. Effects of saturated long-chain fatty acid on mRNA expression of genes associated with milk fat and protein biosynthesis in bovine mammary epithelial cells. Asian-australas. J. Anim. Sci. 27:414. https://doi .org/10.5713/ajas.2013.13499.

Rico, J. E., M. S. Allen, and A. L. Lock. 2014. Compared with stearic acid, palmitic acid increased the yield of milk fat and improved feed efficiency across production level of cows. J. Dairy Sci. 97:1057-1066. https://doi.org/10.3168/jds.2013-7432.

Rico, J. E., V. V. R. Bandaru, J. M. Dorskind, N. J. Haughey, and J. W. McFadden. 2015. Plasma ceramides are elevated in overweight Holstein dairy cows experiencing greater lipolysis and insulin resistance during the transition from late pregnancy to early lactation. J. Dairy Sci. 98:7757-7770. https://doi.org/10.3168/jds.2015 -9519 .

Rosen, E. D., and O. A. MacDougald. 2006. Adipocyte differentiation from the inside out. Nat. Rev. Mol. Cell Biol. 7:885-896. https:// doi.org/10.1038/nrm2066.

Rosen, E. D., C. J. Walkey, P. Puigserver, and B. M. Spiegelman. 2000. Transcriptional regulation of adipogenesis. Genes Dev. 14:1293-1307.

Schmitt, E., M. A. Ballou, M. N. Correa, E. J. DePeters, J. K. Drackley, and J. J. Loor. 2011. Dietary lipid during the transition period to manipulate subcutaneous adipose tissue peroxisome proliferator-activated receptor- $\gamma$ co-regulator and target gene expression. J. Dairy Sci. 94:5913-5925. https://doi.org/10.3168/jds.2011-4230.

Shimabukuro, M., Y.-T. Zhou, M. Levi, and R. H. Unger. 1998. Fatty acid-induced $\beta$ cell apoptosis: A link between obesity and diabetes. Proc. Natl. Acad. Sci. USA 95:2498-2502.

Smith, D. J., and J. P. McNamara. 1989. Lipolytic response of bovine adipose tissue to alpha and beta adrenergic agents 30 days preand 120 days postpartum. Gen. Pharmacol. 20:369-374. https:// doi.org/10.1016/0306-3623(89)90275-9.

Smith, K. L., W. R. Butler, and T. R. Overton. 2009. Effects of prepartum 2,4-thiazolidinedione on metabolism and performance in transition dairy cows. J. Dairy Sci. 92:3623-3633. https://doi.org/ 10.3168/jds.2008-1508.

Smith, T. R., and J. P. McNamara. 1990. Regulation of bovine adipose tissue metabolism during lactation. 6. Cellularity and hormonesensitive lipase activity as affected by genetic merit and energy intake. J. Dairy Sci. 73:772-783. https://doi.org/10.3168/jds.S0022 $-0302(90) 78730-9$

Taha, T. A., T. D. Mullen, and L. M. Obeid. 2006. A house divided: Ceramide, sphingosine, and sphingosine-1-phosphate in programmed cell death. Biochim. Biophys. Acta 1758:2027-2036. https://doi.org/10.1016/j.bbamem.2006.10.018.

Tang, W., D. Zeve, J. M. Suh, D. Bosnakovski, M. Kyba, R. E. Hammer, M. D. Tallquist, and J. M. Graff. 2008. White fat progenitor cells reside in the adipose vasculature. Science 322:583-586. https://doi.org/10.1126/science.1156232.

Thering, B. J., M. Bionaz, and J. J. Loor. 2009a. Long-chain fatty acid effects on peroxisome proliferator-activated receptor- $\alpha$-regulated genes in Madin-Darby bovine kidney cells: Optimization of culture conditions using palmitate. J. Dairy Sci. 92:2027-2037. https://doi .org/10.3168/jds.2008-1749.

Thering, B. J., D. E. Graugnard, P. Piantoni, and J. J. Loor. 2009b. Adipose tissue lipogenic gene networks due to lipid feeding and milk fat depression in lactating cows. J. Dairy Sci. 92:4290-4300. https://doi.org/10.3168/jds.2008-2000.

Tontonoz, P., E. Hu, R. A. Graves, A. I. Budavari, and B. M. Spiegelman. 1994a. mPPAR gamma 2: Tissue-specific regulator of an adipocyte enhancer. Genes Dev. 8:1224-1234. https://doi.org/10 $.1101 /$ gad.8.10.1224.

Tontonoz, P., E. Hu, and B. M. Spiegelman. 1994b. Stimulation of adipogenesis in fibroblasts by PPAR gamma 2, a lipid-activated transcription factor. Cell 79:1147-1156.

Vahmani, P., K. E. Glover, and A. H. Fredeen. 2014. Effects of pasture versus confinement and marine oil supplementation on the expression of genes involved in lipid metabolism in mammary, liver, and adipose tissues of lactating dairy cows. J. Dairy Sci. 97:4174-4183. https://doi.org/10.3168/jds.2013-7290.

Varga, T., Z. Czimmerer, and L. Nagy. 2011. PPARs are a unique set of fatty acid regulated transcription factors controlling both lipid metabolism and inflammation. Biochim. Biophys. Acta 1812:10071022. https://doi.org/10.1016/j.bbadis.2011.02.014.

Wolfrum, C., D. Q. Shih, S. Kuwajima, A. W. Norris, C. R. Kahn, and M. Stoffel. 2003. Role of Foxa-2 in adipocyte metabolism and differentiation. J. Clin. Invest. 112:345-356. https://doi.org/10.1172/ JCI18698.

Wu, Z., N. L. Bucher, and S. R. Farmer. 1996. Induction of peroxisome proliferator-activated receptor gamma during the conversion of 3T3 fibroblasts into adipocytes is mediated by C/EBPbeta, C/ EBPdelta, and glucocorticoids. Mol. Cell. Biol. 16:4128-4136.

Yang, Q.-Y., J.-F. Liang, C. J. Rogers, J.-X. Zhao, M.-J. Zhu, and M. Du. 2013. Maternal obesity induces epigenetic modifications to facilitate Zfp423 expression and enhance adipogenic differentiation in fetal mice. Diabetes 62:3727-3735. https://doi.org/10 $.2337 / \mathrm{db} 13-0433$. 